\title{
DASAR-DASAR DAN RUANG LINGKUP PENDIDIDKAN ISLAM DI INDONESIA
}

\author{
Mastang Ambo Baba \\ PENDAHULUAN
}

\section{A. Latar Belakang Masalah}

Wacana pendidikan dalam Islam tetap actual dan menarik untuk diperbincangkan. Kenyataanya, dunia pendidikan adalah dunia yang tidak pernah sepi dengan kritikan dan debat akademik, bahkan masalah pendidikan tidak pernah selesai sepanjangsejarah kehidupan manusia. ${ }^{1} \mathrm{Hal}$ ini dikelarenakan salah satu keunikan manusia jika dibandingkan dengan kehidupan makhluk lain, tidak pernah sepi dari nilai-nilai luhur yang dicita-citakan.

Islam sebagai agama yang menempatkan pendidikan dalam posisi yang sangat penting. Hal ini pula diakui oleh Malik Fajar, bahwa hubungan Islam dan pendidikan bagaikan dua keeping mata sisi uang, artinya Islam dan pendidikan mempunyai hubungan filosofis yang sangat mendasar, baik secara ontologism, epistemologis, maupun aksiologis. ${ }^{2}$

Pendidikan Islam di Indonesia telah berlangsung sejak masuknya Islam di Indonesia. Hakekat dari pendidikan adalah pembentukan manusia kea rah yang dicita-citakan. Dengan demikian, pendidikan Islam adalah proses pembentukan manusia ke arah yang dicita-citakan oleh Islam.

Esensi dari pendidikan itu ialah dengan melihat unsure dasar dari pendidikan itu sendiri. Unsur dasar pendidikan adalah unsur pemberi dan penerima, unsure tujuan yang baik, cara atau jalan yang baik, serta adanya konteks positif. ${ }^{3}$

Melihat kegiatan pendidikan di Indonesia, maka dapat dikatakan bahwa pendidikan Islam telah banyak memainkan peranannya dalam rangka mencerdaskan kehidupan bangsa, selain itu telah terjadi pula dinamika perkembangan pendidikan Islam di Indonesia. Salah satu yang amat strategis dalam dinamika ini adalah masuknya pendidikan Islam sebagai sebagai subsistem pendidikan nasional.

Dari pernyataan di atas muncul suatu pertanyaan bahwa apakah denagn adanya peranan pendidikan Islam dalam dinamika pendidikan di Indonesia berarti

\footnotetext{
1 Mastuhu, memperdayakan sistem ajaran Islam (Jakarta: Logos Wacana IImu, 1999), h. 29

2 A.Malik Fajar,Reorientasi Pendidikan Islam (Cet.I;Jakarta: Fajar Dunia, 1999), h. 27

3 Noeng Muhajir,Ilmu Pendidikan dan Perubahan Sosial: Suatu Teori Pendidikan (Yogyakarta: Rake Sarasin, 1987), h. 15
} 
unsur-unsur yang menjadi ruang lingkup dalam pendidikan itu sendiri sudah baik atau berhasil? Dengan demikian, yang menjadi obyek kajian dalam makalah ini ialah ruang lingkup pendidikan Islam di Indonesia.

\section{B. RUMUSAN MASALAH}

Berdasrkan permasalahan yang telah diuraikan, berikut ini dirumuskan beberapa permasalahan:

1. Bagaimana dasar pendidikan Islam di Indonesia?

2. Bagaimana ruang lingkup pendidikan Islam di Indonesia?

\section{PEMBAHASAN}

\section{A. Dasar-dasar Pendidikan Islam di Indonesia}

Kata dasar dalam bahasa Arab yaitu asas, dalam bahasa Inggris, foundation, secara etimologi berarti alas, fundamen, pokok atau pangkal segala sesuatu pendapat, ajaran, aturan. ${ }^{4}$ Secara terminology, dasar mengandung arti sebagai sumber adanya sesuatu dan proposisi paling umum dan makna yang paling luas yang dijadikan sumber ilmu pengetahuan, ajaran, atau hukum. ${ }^{5}$

Hasan Langgulung dalam asas-asas Pendidikan Islam menyatakan bahwa berkenaan dengan asas-asas yang dimaksudkan, yaitu asas-asas pendidikan Islam, dapat diuraikan dalam enam asas sebagai berikut:

Pertama, asas historis yang mempersepsi si pendidik dengan hasil-hasil pengalaman pendidikan masa lalu, dengan undang-undang dan peraturanperaturannya, batas-batas dan kekurangan-kekurangannya. Asas-asas sejarah ini meliputi sebagian ilmu sejarah dan arkeoogi, dokumen-dokumen dan bendabenda tertulis yang dapat menoong menafsirkan pendidikan dari segi sejarah dan peradaban.

Kedua, asas sosial yang memberinya kerangka budaya dari mana pendidikan itu bertolak dan bergerak, memindah budaya, memilih, dan mengembangkannya. Asas ini meliputi sebagian ilmu sosiologi dan kependudukan, antropologi, dan etnologi yang dapat menafsiran masyarakat dan kumpulan, milieu dan penduduk, sosialisasi dan perobohan, dan lain-lain.

Ketiga, asas-asas ekonomi yang memberinya perspektif tentang potensipotensi manusia dan keungan serta materi dan persiapan yang mengatur sumbersumbernya dan bertanggung jawab terhadap anggaran belanjanya. Asas ini

4 Tim Penyusun Kamus Pusat Pembinaan dan Pengembangan Bahasa Departemen Pendidikan dan Kebudayaan, Kamus Besar Bahasa Indonesia ( Jakarta: Balai Pustaka, 1994), h. 211

5 Hery Nur Aly, ilmu Pendidikan Islam (Jakarta:Logos Wacana Ilmu, 1999), h. 19. 
meliputi sebagian ilmu ekonomi dan akunting, budgeting dan perencanaan yang dapat menolong dalam investasi yang lebih ideal, pelayanan yang lebih memuaskan, dan kemampuan yang lebih tinggi.

Keempat, asas politik dan administrasi yang memberinya bingkai ideology (aqidah) dari mana ia bertolak untuk mencapai tujuan yang dicita-citakan dan rencana yang telah dibuat. Asas ini meliputi sebagian ilmu administrasi dan organisasi, undang-undang, dan perundang-undangan yang dapat menafsirkan susunan organisasi pendidikan dan mengarahkan geraknya.

Kelima, asas-asas psikologis yang memberinya informasi tentang watak pelajar-pelajar, guru-guru, cara-cara baik dalam praktik, pencapaian dan penilaian, dan pengukuran dan bimbingan. Asas ini meliputi sebagian ilmu tingkah laku, biologi dan fisiologi, dan komunikasi yang sesuai untuk memahami pengajaran dan proses belajar, perkembangan dan pertumbuhan, kematangan, kemampuan dan kecerdasan, persepsi dan perbedaan-perbedaan perseorangan, minat, dan sikap.

Keenam, asas filsafat yang selalu berusaha memberinya kemampuan untuk memilih yang lebih baik, memberi arah suatu sistem, mengontrolnya, dan memberi arah kepada semua asas-asas yang lain. Asas ini meliputi sebagian ilmu etika dan estetika, ideology dan logika untuk memberi arah kepada pengajaran dan menyelaraskan interaksi-interaksi masing-masing, menyusun sistemnya sesudah siteliti dan dikritik, dianalisis dan dibuat sistensis. ${ }^{6}$

Pendapat mengenai dasar dan asas pendidikan Islam tersebut terlihat sudah demikian lengkap, namun belum sempurna, karena belum memasukkan dasar atau asas (agama) Islam yang justru menjadi karakter dari pendidikan Islam tersebut. $^{7}$

Dasar dalam pendidikan Islam dapat dibagi kepada tiga kategori:

1.Dasar pokok; 2. Dasar tambahan; dan 3. Dasar operasional

Dengan berdasarkan pada Al-Qur'an dan As-Sunnah, pendidikan Islam tidak hanya akan menemukan berbagai isyarat tentang pentingnya membangun sistem pendidikan Islam yang lengkap : visi, misi, tujuan, kurikulum, dan lainnya, melainkan pula menemukan prinsip-prinsip yang harus dipegang teguh dalam mengembangkan pendidikan Islam. Melalui kajian al-Qur'an dan Sunnah dapat dijumpai beberapa prinsip yang terkait erat dengan pengembangan pendidikan Islam. Al-Qur'an As-Sunnah menawarkan prinsip hubungan yang erat, harmonis dan seimbang dengan Tuhan, manusia dan alam, pendidikan untuk semua

${ }^{6}$ Lihat Hasan Langgulung, Asas-asas Pendidikan Islam (Cet.I;Jakarta: Pustaka al-Husna, 1978), h. 6-7

7 Lihat Abdul Mujib, Yusuf Mudzakir, IImu Pendidikan Islam (Cet.I; Jakarta: Kencana,2006), h. 45. 
(education for all), pendidikan untuk seumur hidup ( long life education ), pendidikan yang berorientasi pada kualitas, pendidikan yang unggul, pendidikan yang terbuka, demokratis, adil, egaliter, dinamis, manusiawi dan sesuai dengan fitrah manusia, seimbang antara pendidikan yang mendukung kecerdasan akal, spiritual, sosial, emosional, kinestetis, seni, etika, dan lainnya, professional, berorientasi pada masa depan, menjadikan pendidikan sebagai alat untuk mewujudkan kedamaian, kesejahteraan, keamanan, dan ketentraman, dan lainnya. ${ }^{8}$

B. Ruang Lingkup Pendidikan Islam

Kalau dipaahami serta dihayati tentang pengertian, sesungguhnya telah tersirat adanya ruang lingkup Pendidikan Islam. Namun untuk lebih jelasnya, ruang lingkup pendidikan Islam tersebut dapat dikemukakan sebagai berikut.

Pertama, teori-teori dan konsep-konsep yang diperlukan bagi perumusan desain pendidikan dengan berbagai aspeknya : visi, misi, tujuan, kurikulum, proses belajar mengajar, dan sebagainya. Teori-teori dan konsep-konsep tersebut dibangun dari hasil kajian yang ilmiah dan mendalam terhadap sumber ajaran Islam yang terdapat dalam al-Qur'an ad as-Sunnah, serta dari berbagai disiplin ilmuyang relevan: sejarah, filsafat, psikologi, sosiologi, budaya, politik, hukum, etika, manajemen, teknologi canggih, dan sebagainya.

Kedua, teori dan konsep yang diperlukan untuk kepentingan praktik pendidikan, yaitu memengaruhi peserta didik agar mengalami perubahan, peningkatan, dan kemajuan, baik dari segi wawasan, keterampilan, mental spiritual, sikap, pola pikir, dan kepribadiannya. Berbagai komponen keterampilan terapan yang diperlukan dalam praktik pendidikan,berupa praktik padagogis, didaktik, dan metodik, didasarkan pada teori-teori dan konsep-konsep yang terdapat dalam ilmu pendidikan Islam.

Selain itu, menurut Nur Uhbiyati, ruang lingkup pendidikan Islam sangat luas, yang didalamnya banyak segi atau pihak yang ikut terlibat baik langsung maupun tidak langsung. ${ }^{9}$

Dengan demikian, penulis akan membahas tentang pihak-pihak yang terlibat dalam pendidikan Islam yang menjadi ruang lingkupnya.

1. Perbuatan Mendidik itu Sendiri

\footnotetext{
8 Lihat A. Abuddin Nata, IImu Pendidikan Islam: dengan pendekatan multidispliner (normative perenealis, sejarah, filsafat, psikologi, sosiologi, manajemen, teknolgi, informasi, kebudayaan, politik, hukum), Edisi I (Cet.II; Jakarta: Rajawali Press, 2010), h. 31-34

${ }_{9}$ Nur Uhbiyati, Ilmu Pendidikan Islam, Edisi Revisi ( Cet.II; bandung: CV. Pustaka Setia, 1998), h.13.
} 
Yang dimaksud dengan perbuatan pendidik adalah seluruh kegiatan, tindakan atau perbuatan dan sikap yang dilakukan oleh pendidik sewaktu menhadapi/ mengasuh peserta didik. Atau dengan istilah lain yaitu sikap atau tindakan yang menuntun, membimbing, memberi pertolongan dari seseorang pendidik kepada peserta didik menuju kepada tujuan pendidikan Islam. Dalam perbuatan mendidik sering disebut dengan istilah tahzib. ${ }^{10}$

\section{Pelaku Pendidikan}

a. Pendidik

Sebagaimana diketahui bahwa tujuan akhir pendidikan Islam ialah terciptanya insan kamil. Menurut Muhaimin, insan kamil adalah manusia yang mempunyai wajah Qurani, terciptanya insane yang memilki dimensi religious, budaya dan ilmiah.

Untuk mengaktualisasikan tujuan tersebut dalam pendidikan Islam, pendidik bertanggung jawab mengantarkan manusia kea rah tujuan tersebut. Justru itu, keberadaan pendidik dalam dunia pendidikan sangat krusial, sebab kewajibannya tidak hanya mentransformasikan pengetahuan (knowledge), tetapi juga dituntut menginternalisasikan nilai-nilai (volluelqimah) pada peserta didik. Bentuk nilai yang diintemalisasikan paling tidak meliputi : nilai etika (akhlak), estetika, sosial, ekonomis, politik, pengetahuan, pragmatis, dan nilai ilahiyah.

Secara factual, palaksanaan internalisasi nilai dan transformasipengetahuan pada peserta didik secara integral merupakan tugas yang cukup berat di tengah kehidupan masyarakat yang kompleks apalagi pada era globalisasi dan modernisasi. Yugas yang berat tersebut ditambah lagi dengan pandangan sebagian masyarakat yang melecehkan keberadaan pendidik di sekolah, diluar sekolah maupun dalam kehidupan sosial masyarakat. Hal ini disebabkan karena profesi pendidik dari segi materil kurang menguntungkan karena sebagian masyarakat dalam era globalisasi ini dipengaruhi paham materialisme yang menyebabkan mereka bersifat materialistik.

Berbeda dengan gambaran tentang pendidik pada umumnya pendidik Islam, adalah orang yang bertanggung jawab terhadap perkembangan peserta didik dalam mengembangkan potensinya, dan dalam pencapaian tujuan pendidik baik dalam aspek kognitif, afektif maupunpsikomotorik. ${ }^{11}$

Pendidik dalam pendidikan Islam adalah setiap orang dewasa yang karena kewajiban agamanya bertanggung jawab atas pendidikan dirinya dan orang lain.

10 Ibid, h.14.

${ }^{11}$ Hasan Langgulung, beberapa Pemikiran Tentang Pendidikan Islam (Bandung, Al-Ma'arif, 1980), h. 147. 
Sedangkan yang menyerahkan tanggung jawab dan amanat pendidikan adalah agama, sementara yang menerima tanggung dan amanat adalah setiap orang dewasa. Ini berarti bahwa pendidik merupakan sifat yang lekat pada setiap orang karena tanggungbjawabnya atas pendidikan.

Dalam konteks pendidikan Islam, pendidik disebut dengan murabbi, muallim dan muaddib. ${ }^{12}$ Ketiga tern itu, mempunyai makna yang berbeda, sesuai dengan konteks kalimat, walaupun dalam situasi tertentu mempunyai kesamaan makna.

Dalam konsep pendidikan Islam, Allah SWT. Ditempatkan sebagai pendidik yang Maha Agung, yang kemudian mendidik Rasul Allah SWT dengan sistem pendidikan yang terbaik, sehingga menempatkan diri Rasulullah SAW pada kedudukan sebagai tokoh pendidik pertama. Tugas dan wewenang itu dilimpahkan kepada kedua orang tua dengan memberinya muatan nilai-nilai keagamaan. Tugas dan wewenang itu kemudian dilimpahkan lagi kepada tenaga professional, yaitu para pendidik.

Untuk itu menurut Abd al-Rahman al-Nahlawi dalam Jalaluddin. ${ }^{13}$, mengatakan syarat seorang pendidik meliputi sifat dan perilaku seperti : (1) harus memiliki sifat Rabbani, (2) menyempurnakan sifat Rabbani dengan keikhlasan, (3) memilki rasa sabar, (4) memilki kejujuran dengan menerangkan apa yang diajarkan dalam kehidupan pribadi, (5) meningkatkan wawasan dan kajian, (6) menguasai variasi serta metode mengajar, (6) mampu bersikap tegas dan meletakkan sesuatu sesuai dengan tempatnya (proposisi) sehingga ia akan mampu mengendalikan diri dan muridnya, (8) memahami dan menguasai psikologi anak dan memperlakukan mereka sesuai dengan kemampuan intelektual dan kesiapan psikoogisnya, (9) mampu mengetahui fenomena kehidupan sehinggamemahami berbagai kecenderungan dunia beserta dampak yang akan ditimbulkan bagi peserta didik, dan (10) dituntut untuk memilki sifat adil (objektif) terhadap peserta didik.

b.Peserta didik

Peserta didik salah satu komponen dalam sistem pendidikan Islam. Peserta didik merupakan "raw material (bahan mentah) di dalam proses transformasi yang disebut pendidikan. Berbeda dengan kompenen-komponen lain dalam sistem pendidikan karena menerima "materil" ini sudah setengah jadi, sedangkan komponen-komponen lain dapat dirumuskan dan disusun sesuai dengan keadaan fasilitas dan kebutuhan yang ada.

Peserta didik secara formal adalah orang yang sedang berada pada fase pertumbuhan dan perkembangan baik secara fisik maupun psikis, pertumbuhan dan

\footnotetext{
12 Lihat Syekh Muhammmad al-Naquib al-attas, The Concept of education in Islam (Kuala Lumpur: Muslim Youth Men of Malaysia ABM, 1980), h.14.

13 Jalaluddin, Teologi Pendidikan (Jakarta : PT.RajaGrafindo Persada, 2001).
} 
perkembangan merupakan ciri dari seorang pendidik. Pertumbuhan menyangkut fisik, perkembangan menyangkut psikis.

Menurut pasal 1 ayat 4 UU R.I No.20 tahun 2003 tentang sistem Pendidikan Nasional, peserta didik adalah anggota masyarakat yang berusaha mengembangkan dirinya melalui proses pendidikan pada jalur jenjang dan jenis pendidikan tertentu.

Syamsul Nizar, dalam H. Ramayulis mendeskripsikan enam kriteria peserta didik: ${ }^{14}$

1. Peserta didik bukanlah miniature orang dewasa, tetapi memilki dunianya sendiri.

2. Peserta didik memilki periodisasi perkembangan dan pertumbuhan.

3. Peserta didik merupakan makhluk Allah yang memilki perbedaan individu baik disebabkan oleh faktor bawaan maupun lingkungan di mana ia berada.

4. Peserta didik merupakan dua unsur utama jasmani dan rohani, unsur jasmani memilki daya fisik dan unsur rohani memilki daya akal hati nurani dan nafsu.

5. Peserta didik adalah manusia yang memilki potensi atau fitrah yang dapat dikembangkan dan berkembang secara dinamis.

Dalam proses pendidikan peserta didik di samping sebagai objek juga sebagai subjek. Oleh karena itu agar seorang pendidik berhasil dalam proses pendidikan, maka ia harus memahami peserta didik dengan segala karakteristiknya. Diantara aspek yang harus dipahami oleh pendidik yaitu: (1) kebutuhannya, (2) dimensidimensinya, (3) intelegansinya, (4) kepribadiannya. ${ }^{15}$

Pendidikan Islam memahami peserta didik atas dasar pendekatan terhadap hakikat kejadian manusia yang menempatkannya selaku makhluk Allah yang mulia. Kemuliaan yang disandang manusia harus dihargai, dan perlakuan terhadapnya harus dibedakan dari perlakuan terhadap makhluk lain. Kemuliaan itu sendiri tidak mungkin dapat terwujud dengan mengendalikan diri sendiri, tanpa adanya upaya pendidikan dan pembinaan yang sungguh-sungguh meliputi pembinaaan aspek jasmaniah maupun rohani ,fisik material maupun mental spiritual. ${ }^{16}$

Kriteria peserta didik dari aspek formal adalah anak yang sedang tumbuh dan berkembang, baik fisik maupun psikis, untuk mencapai tujan pendidikan diperlukan suatu lembaga pendidikan formal.. kriteria ini berawal pada usia 7 tahun, saat anak sudah dapat menerima adanya gezag, hingga memungkinkan ia menyadari dan mematuhi disiplin. Secara informal. Pendidikan Islam mengetengahkan konsep

\footnotetext{
14 Ramayulis, Ilmu Pendidikan Islam (Cet. VII; Jakarta: Kalam Mulia, 2008), h. 77-78

15 Lihat op.Cit., 78-79

16 Muhaimin, Paradigma Pendidikan Islam: Upaya mengaktifkan pendidikan Agam Islam di Sekolah (Bandung: PT. Remaja Rosdakarya, 2002).
} 
pendidikan sepanjang hayat (life long education). Selama menjalani rentang kehidupan itu manusia memerlukan bimbingan, pembentukan, pengarahan, dan pengamalan, baik melalui intervensi langsung dari pada pendidik maupun dari usaha sendiri. Semuanya itu dilaksanakan secara bertahap dan berbeda, disesuaikan dengan kebutuhan pada tingkat perkembangan masing-masing.

Pendidikan Islam mengacu kepada potensi yang ada pada diri manusia. Potensi laten dalam konsep pendidikan Islam disebut fitrah, yang berarti kekuatan asli yang terpendam didalam diri manusia yang dibawanya sejak lahir. ${ }^{17}$ Yang akan menjadi pendorong serta penentu bagi kepribadiannya, serta yang dijadikan alat untuk pengabdian dan ma'rifatullah. Jadi bimbingan terhadap pengembangan fitrah, harus menuju kea rah yang jelas.

Berdasarkan potensi penciptaannya, maka perkembangan manusia meliputi seluruh aspek yang dibutuhkan oleh manusia dalam kehidupannya baik statusnya sebgai manusia yang bertuhan, makhluk individu, makhluk sosial, makhluk bermoral, makhluk berperadaban dan sebagainya. Aspek perkembangan ini merupakan potensi yang mendukung pengembangan menusia menjadi sosok manusia seutuhnya, secara optimal dan berimbang, agar mampu menjalankan amanat dalam statusnyaselaku hamba Allah maupunkhafila-Nya. Dengan demikian perkembangan manusia baru akan menjadi sempurna (insane kamil) bila perkembangan potensi dirinya yang mencakup keseluruhan aspek perkembangan itu dilakukan secara total dan maksimal.

\section{Komponen-komponen Pendidikan Islam}

\section{a. Tujuan Pendidikan}

Seperti yang dimaklumi bersama, bahwa dalam masyarakat yang dinamis, pendidikan memegang peran yang menentukan terhadap eksistensi dan perkembangan masyarakat. Karena pendidikan merupakan usaha untuk mentransfer dan mentransformasikan pengetahuan serta menginternalisasikan nilai-nilai kebudayaan dalam segala aspek dan jenisnyakepada generasi penerus. Demikan pula peran pendidikan Islam di kalangan umat Islam merupakan salah satu bentuk manifestasi dari cita-cita Islam untuk melestarikan, mentransformasikan dan mengintemalisasikan nilai-nilai Islam tersebut kepada generasi penerusnya, sehinggan nilai cultural-religius yang dicita-citakan dapat tetap berfungsi fan berkembang dalam masyarakat dari waktu ke waktu.

Pendidikan Islam, seperti pendidikan pada umumnyaberusaha membentuk pribadi manusia, harus melalui proses yang panjang, dengan hasil yang tidak dapat diketahui dengan segera. Berbeda dengan membentuk benda mati yang ddapat dilakukan sesuai

\footnotetext{
17 Jalaluddin,Op.cit
} 
dengan keinginan pembentuknya. Oleh karena itu, dalam pembentukan tersebut diperlukan suatu perhitungan yang matang dan hati-hati berdasarkan pandangan dan rumusan-rumusan yang jelas dan tepat.

Sehubungan dengan hal tersebut, pendidikan Islam harus memahami dan menyadari betul apa sebenarnya yang ingin dicapai dalam proses pendidikan. Sesuatu yang akan dicapai tersebut dala istilah pendidikan disebut dengan "tujuan pendidikan".

Tujuan pendidikan merupakan masalah sentral dalam pendidikan sebab, tanpa perumusan yang jelas tentang tujuan pendidikan, perbuatan menjadi acak-acakan, tanpa arah, bahkan bisa sesat atau salah langkah. Oleh karena itu, perumusan tujuan dengan tegas dan jelas, menjadi inti dari seluruh pemikiran pedagosis dan perenungan filosofi. ${ }^{18}$

Dikatakan lebih lanjut bahwa tujuan pendidikan itu penting, disebabkan karena secara implicit dan eksplisit di dalamnya terkandung hal-hal yang sangat asasi, yaitu pandangan hidup dan filsafat hidup pendidiknya, lembaga penyelenggara pendidikan, dan Negara, dimana pendidikan itu dilaksanakan.

b. Kurikulum Pendidikan Islam

Kurikulum merupakan salah satu komponen yang sangat menentukan dalam suatu sistem pendidikan, karena itu kurikulum merupakan alat untuk mencapai tutjuan pendidikan dan sekaligus sebagai pedoman dalam pelaksanaan pengajaran pada semua jenis dan tingkat pendidikan.

Tujuan pendidikan di suatu bangsa atau Negara ditentukan oleh falsafah dan pandangan hidup bangsa atau Negara tersebut. Berbedanya falsafah dan pandangan hidup suatu bangsa atau Negara menyebebkan berbeda pula tujuan yang hendak dicapai dalam pendidikan tersebut dan sekaligus akan berpengaruh pula terhadap Negara tersebut. Begitu pula perubahan politik pemerintahan suatu Negara mempengaruhi pula bidang pendidikan, yang sering membawa akibat terjadinya perubahan kurikulum yang berlaku. Dengan demikian kurikulum senantiasa bersifat dinamis guna lebih menyesuaikan dengan berbagai perkembangan yang terjadi. Setiap penduduk harus memahami perkembangan kurikulum, karena merupakan suatu formulasi pedagogis yang paling penting dalam konteks pendidikan, dalam kurikulum akan tergambar bagaimana usaha yang dilakukan membantu peserta didik dalam mengembangkan potensinya, berupa fisik, intelektual, emosional, dan sosial, keagamaan dan sebagainya.

18 Kartini Kartono, Pengantar Ilmu Pendidikan Teoritis (Bandung: Mandar Maju, 1992), h. 204 
Dengan memahami kurikulum, para pendidik dapat memilih dan menentukan tujuan pendidikan. Metode, teknik, media pengajaran dan alat evaluasi pengajaran yang sesuai dan tepat. Untuk itu dalam melakukan kajian terhadap keberhasilan sistem pendidikan ditentukan oleh tujuan yang realities, dapat diterima oleh semua pihak, sarana organisasi yang baik, intensitas pekerjaan yang realistis tinggi dan kurikulum yang tepat guna. Oleh karena itu, sudah sewajarnya para pendidik dan tenaga kependidikan bidang pendidikan Islam memahami kurikulum serta berusaha mengembangkannya.

c. Metode Pendidikan Islam

Secara etimologi, metode dalam bahasa Arab, dikenal dengan istilah thariqah yang berarti langkah-langkah strategis yang dipersiapkan untuk melakukan suatu pekerjaan. Bila dihubungkan dengan pendidikan, maka metode itu harus diwujudkan dalam proses pendidikan, dalam rangka mengembangkan sikap mental dan kepribadian agar peserta didik menerima pelajaran dengan mudah, efektif dan dapat dicerna dengan baik. Metode mengajar dapat diartikan sebagai cara yang dipergunakan oleh pendidik dalam membelajarkan peserta didik saat berlangsungnya proses pembelajaran.

Secara terminology, para ahli mendefinisikan metode sebagai berikut:

1. Hasan langgulung mendefinisikan bahwa metode adalah cara atau jalan yang harus dilalui untuk mencapai tujuan pendidikan

2. Abd. Al-Rahman Ghunaimah mendefinisikan bahwa metode adalah cara-cara yang praktis dalam mencapai tujuan pengajaran.

3. Ahmad Tafsir mendefinisikan bahwa metode mengajar adalah cara yang paling tepat dan cepat dalam mengajarkan mata pelajaran. ${ }^{19}$

Berdasarkan beberapa devinisi di atas dapat disimpulkan bahwa metode adalah seperangkat cara, jalan dan teknik yang digunakan oleh pendidik dalam proses pembelajaran agar peserta didik dapat mencapai tujuan pembelajaran atau menguasai kompetensi tertentu yang dirumuskan dalam silabi mata pelajaran.

Dalam pandangan filosofis pendidikan, metode merupakan alat yang dipergunakan untuk mencapai tujuan pendidikan. Alat itu mempunyai fungsi ganda, yaitu bersifat polipragmatis dan monopragmatis.

Polipragmatis bilamana metode mengandung kegunaan yang serba ganda (multipurpose), misalnya suatu metode tertentu pada suatu situasi tertentu dapat dapat digunakan untuk membangun atau memperbaiki sesuatu. Kegunaannya dapat tergantung pada si pemakai atau pada corak, bentuk, dan kemampuan metode sebagai

19 Ahmad Tafsir, Metodologi Pengajaran Agama Islam (Cet.III; Bandung: PT. Remaja Rosdakarya, 1996), h. 9 
alat, sebaliknya, monopragmatis bilamana metode mengandung satu macam kegunaan untuk satu macam tujuan.

Menurut M. Arifin dalam H. Ramayulis, penggunaan metode bersifat konsisten, sistematis dan kebermaknaan menurut kondisi sasarannya. Mengingat sasaran metode adalah manusia, sehingga pendidik dituntut untuk berhati-hati dalam penerapannya. ${ }^{20}$

Motode pendidikan Islam dalam penerapannya banyak menyangkut permasalahan individual atau sosial peserta didik dan pendidik itu sendiri, sehingga dalam menggunakan metode seorang pendidik harus memperhatikan dasar-dasar umum metode pendidik Islam. Sebab, metode pendidikan itu hanyalah merupakan sarana atau jalan yang ditempuh oleh seorang pendidik haruslah mengacu pada dasar-dasar metode pendidikan tersebut. Dalam hal ini tidak bisa terlepas dari dasar agamis, biologis, psikoogis, dan sosiologis. ${ }^{21}$

d. Media Pendidikan

Media dalam kegiatan proses belajar memang berfungsi instrumental, dengan kata lain media berarti hanya sekedar "alat" saja, bukan tujuan. Alat untuk membantu proses belajar, alat untuk mempermudah pemahaman masalah yang sedang dibahas, alat untuk mempermudah mengungkapkan hal-hal yang rumit. Jadi sebagai alat, media bisa digunakan untuk berbagai tujuan, tetapi tidak untuk semua tujuan. Karena setiap media memiliki ciri (karakteristik), memilki kekhasannya masing-masing, sehingga hany tetap digunakan untuk tujuan-tujuan yang khas dan sesuai pula.

Dalam perspektif dan metodologi pendidikan kritis, media juga adalah "bahasa"nya para fasilitator. Media digunakan oleh para fasilitator bukan sematamata karena efektif membantu proses pemahaman, tetapi karena penggunaan media itu sendiri merupakan suatu keharusan jika ingin taat-asas pada filosofi pendidikan kritis yang menekankan mutlaknya para partisipan belajar dan memproduksi pengetahuan dari pengalaman mereka sendiri. Partisipan seharusnya tidak mendapatkan pengetahuan dari hafalan teori, kaidah dan rumus-rumus orang lain dan, untuk itu seorang fasilitator tidak akan bisa melakukannya jika ia hanya bicara melulu, apalagi pidato, khotbah atau ceramah monolog tanpa diskusi dengan para partisipan. Bahkan, diskusi mestinya terjadi antara para partisipan sendiri, sementara fasilitator hanya menyediakan sarana dan prosesnya saja. Sarana dan proses itulah media, bahasa-nya para fasilitator. Ini yang membedakan seorang fasilitator dengan seorang manajer atau guru atau dosen. Kalaupun manajer, guru, dan dosen tersebut menggunakan media yang sama, biasanya hanya sebagai peraga atau

20 H. Ramayulis, op.cit., h. 185

21 Lihat Ibid., h. 185-188 
"penggambaran" (illustration), sebagai pemanis dan pemikat omongan atau ceramah dan kuliahnya agar lebih menarik dan tidak membosankan. ${ }^{22}$

Bagi seorang fasilitator, media bukan hanya berfungsi sebagai ilustrasi, tetapi sekaligus sebagai "sandi" (code) untuk mengajak partisipan berpikir tentang sesuatu, mendiskusikannya bersama, berdialog untuk menemukan suatu kesimpulan dan jawaban mereka sendiri. Dengan cara demikian, fasilitator menjadikan sandi tersebut sebagai suatu "gambaran yang hidup" (animation) tentang suatu kejadian, gejala, atau permasalahan nyata tertentu. Itu pula sebabnya mengapa fasilitator sering juga disebut sebagai "animator" pada saat partisipan mulai berpikir, berdiskusi dan berdialog itulah berlangsung pula suatu proses pemberian arti, pengertian, pemaknaan (kodifikasi) atas gambaran hidup keadaan , gejala, atau permasalahan yang ditampilkan melalui media. Kemudian pada saat mereka mencapai suatu kesimpulan bersama, mereka telah melahirkan suatu pemahaman dan kesadaran baru, suatu pengetahuan yang melihat kejadian, gejala dan permasalahan secara kritis.

Walhasil, semakin jelas pula bahwa penggunaan media oleh seorang fasilitator dalam proses pendidikan kritis didasari pada suatu landasan filosofi dan teori perubahan sosial yang sangat mendasar. Jika, dalam kenyataan kesehariannya, mereka Nampak sedemikian sederhana dan terkesan sangat praktis dengan berbagai media tersebut, tidak berarti mereka tidak bisa memiliki landasan filosofi dan teoritis yang kuat. Dengan kata lain, media sebagai bahasa dan sandi di tangan seorang fasilitator pendidikan kritis, adalah pemicu awal dari keseluruhan proses perubahan sosial yang sesungguhnya.

e. Evaluasi Pendidikan Islam

Evaluasi sangat dibutuhkan dalam berbagai kegiatan kehidupan manusia seharihari, karena disadari atau tidak, sebenarnya sudah sering dilakukan, baik untuk diri sendiri maupun kegiatan soal lainnya. Hal ini dapat dilihat mulai dari berpakaian, setelah berpakaian ia berdiri dihadapan kaca apakah penampilannya sudah wajar atau belum.

Dalam pendidikan Islam evaluasi merupakan salah satu komponen sistem pendidikan Islam yang harus dilakukan secara sistematis dan terencana sebagai alat untuk mengukur keberhasilan atau target yang akan dicapai dalam proses pendidikan Islam dan proses pembelajaran. Pembelajaran adalah kegiatan yang disengaja (sadar) oleh peserta didik dengan arahan, bimbingan atau bantuan dari pendidik untuk memperoleh suatu perubahan. Perubahan yang diharapkan untuk meliputi aspek

22 Toro Rahardjo, Pendidikan Popular: Membangun Kesadaran Kritis (Cet.II; Yogyakarta: Insist Press, 2005), h. 105 
kognitif (pengetahuan), efektif (sikap dan tingkah laku) dan psikomotorik (gerakan ragawi/ keterampilan).

Perubahan yang diharapkan itu dinamakan dengan kompetensi (kemampuan melakukan sesuatu), dirumuskan sebelumnya dalam disain pembelajaran. Rumusan tersebut biasanya dinamakan dengan tujuan pembelajaran (dulu tujuan intruksional, sekarang kompetensi). Mulai dari kompetensi dasar, kompetensi mata pelajaran, kompetensi lintas disiplin, dan kompetensi lulusan yang dalam GBPP kemudian dijabarkan menjadi beberapa indikator. Untuk mengetahui sejauh mana tujuan pembelajaran atau kompetensi yang diharapkan tercapai oleh peserta didik diperoleh melalui evaluasi.

Kalau dikaitkan dengan pengertian pendidikan Islam, maka evaluasi itu berarti suatu kegiatan untuk menentukan taraf kemajuan suatu pekerjaan di dalam pendidikan Islam, Al-Wahab, ${ }^{23}$ menyatakan bahwa evaluasi atau tagwim itu adalah sekumpulan kegiatan-kegiatan pendidikan yang menentukan atas suatu perkara untuk mengetahui tercapainya tujuan akhir pendidikan dan pengajaran sesuai dengan program-program pelajaran yang beraneka ragam. Sedang daftar hasil kegiatan pada waktu itu berupa kelemahan-kelemahan kelebih-lebihan, evalusi menitikberatkan pada proses pendidikan dan pengajaran peletakannya berupa catatan-catatan latihan dan juga pertemuan tatap muka.

f. Lembaga Pendidikan Islam

Lembaga pendidikan merupkan salah satu sistem yang memungkinkan berlangsungnya pendidikan secar berkesinambungan dalam rangka mencapai tujuan pendidikan. Adanya kelembagaan dalam masyarakat, dalam rangka proses pembudayaan umat, merupakan tugas dan tanggung jawabnya yang semakin berat. Tanggung jawab lembaga pendidikan tersebut dalam segala jenisnya menurut pandangan Islam adalah erat kaitannya dengan usaha menyukseskan misi sebagai seorang muslim. ${ }^{24}$

Lembaga pendidikan Islam merupakan hasil pemikiran yang dicetuskan oleh kebutuhan-kebutuhan masyarakat yang didasari, digerakkan, dan dikembangkan oleh jiwa Islam (al-Quran dan al-Sunnah). Lembaga pendidikan Islam secara keseluruhan, bukanlah sesuatu yang datang dari luar, melainkan dalam pertumbuhan dan perkembangannya mempunyai hubungan yang erat dengan kehidupan Islam secara umum. Islam telah mengenal lembaga pendidikan sejak dtik-detik awal turunnya

23 Abd. Al-Salam, Abd al-Wahab, Al-Tarbiyah wa Fan al-Tadris (Mesir: Dar al-Salam, 1418 H), h. 209

24 M. Arifin, Filsafat Pendidikan Islam (Cet. III; Jakarta: Bumi Aksara, 1993), h. 39 
wahyu kepada Nabi Muhammad SAW. Rumah al-Arqam ibn Abi al-Arqam merupakan lembaga pendidikan yang pertama. ${ }^{25}$

Lembaga pendidikan Islam bukanlah lembaga beku, tetapi fleksibel, berkembang dan menurut kehendak waktu dan tempat. Hal ini seiring dengan luasnya daerah Islam yang membawa dampak pada pertambahan jumlah penduduk Islam. Dan adanya keinginan untuk memperoleh aktivitas belajar yang memadai. Sejalan dengan makin berkembangnya pemikiran tentang pendidikan, maka didirikanlah berbagai macam lembaga pendidikan yang belajar dengan sistem klasikal, yaitu berupa madrasah. Lembaga pendidikan inilah yang disebut dengan lembaga pendidikan formal.

\section{ANALISIS PENGEMBANGAN}

Dunia pendidikan di Indonesia saat ini tengah menghadapi prolema yang cukup berat dan kompleks. Keadaan bangsa Indonesia seperti ini harus dicarikan pemecahannya melalui upaya pendidikan, karena pendidikanlah merupakan sarana yang dapat memberikan bekal kepada manusia untuk membudayakan dirinya, membebaskan dirinya dari kebodohan, keterbelakangan bahkan penindasan dan kemiskinan.

Dilihat dari segi fungsinya pendidikan di Indonesia diharapkan dapat mengembangkan kemampuan serta meningkatkan mutu kehidupan dan martabat manusia Indonesia dalam rangka upaya mewujudkan tujuan nasional. Fungsi pendidikan yang demikian itu juga masih belum terlihat hasilnya secara actual. Keadaan menunjukkan bahwa mutu kehidupan dan martabat manusia Indonesia di mata dunia internasional amat terpuruk. Daya saing kualitas sumber daya manusia Indonesia masih berada di bawah kualitas sumber daya manusia di negarnegara di kawasan Asia Tenggara. Demikian pula citra bangsa Indonesia dimata dunia Internasional tampil dalam sosoknya sebagai bangsa yang kurang beradab. Bangsa Indonesia dianggap sebagai bangsa yang kejam, sadis, bengis, dan menakutkan.

Dilihat dari segi tujuannya, pendidikan nasional, bertujuan mencerdaskan kehidupan bangsa dan mengembangkan manusia Indonesia seutuhnya. Tujuan pendidikan nasional tersebut tampak ideal, dan jika dapat diwujudkan, maka akan dihasilkan manusia yang utuh, sempurna, terbina seluruh potensi jasmani, intelektual, emosional, sosial dan sebagainya, sehingga dapat diserahkan tanggung jawab untuk mengemban tugas baik yang berkenaan dengan kepentingan pribadinya, maupun masyarakat dan bangsanya. Namun demikian dalam kenyataan masih terdapat kesenjangan antara tujuan pendidikan yang diharapkan dengan realitas lulusan

25 Hasan Abd. Al-Ali, Tarbiyah al-Islamiyah fi al-Qarniy al-Rabi' al-Hijry ( Mesir: Dar al-Fikr, 1978), h. 181. 
pendidikan. Lulusan pendidikan saat ini cenderung bersikap sekuler, materialistik, rasionalistik, hedonistik, yaitu manusia yang cerdas intelektualnya dan terampil fisiknya, namun kurang terbinamental spiritualnya, dan kurang memiliki kecerdasab emosional. Akibat dari keadaan yang demikian itu, kini banyak sekali para pelajar yang terlihat dalam tawuran, tindakan criminal, pencurian, penyalahgunaan obat-obat terlarang, pemerkosaan, dan lain sebagainya.

Dari kesempatan yang diberikan, dalam Sistem Pendidikan Nasional disebutkan bahwa setiap warga Negara mempunyai hak yang sama untuk memperoleh pendidikan. Namun dalam kenyataan masih banyak warga Indonesia yang belum mengenyam pendidikan sebagai akibat dari ketidakmampuan dalam bidang ekonomi. Pendidikan saat ini, khususnya pendidikan yang bermutu hanya dapat dinikmati dan dimonopoli oleh segelintir orang yang mampu saja. Sedangkan masyarakat pada umumnya hanya mendapatkan pendidikan yang kurang menjanjikan masa depannya. Untuk itu mengatasi masalah ini maka perlu diperbanyak lembaga-lembaga pendidikan yang menyediakan pendidikan yang bermutu dengan biaya yang terjangkau oleh masyarakat. lembaga pendidikan tersebut harus berasal dari masyarakat dan untuk masyarakat, seperti halnya pesantren. Kni sudah saatnya masyarakat memberikan perhatian yang lebih besar dalam memberdayakan pesantren sebagai pendidikan alternative yang berkualitas untuk kepentingan masyarakat.

Dari segi penyelenggaraannya, pendidikan dilaksanakan melalui dua jalur; jalur pendidikan sekolah dan jalur pendidikan luar sekolah. Namun dalam prakteknya perhatian pemerintah selama ini hanya diberikan terhadap jalur pendidikan sekolah. Sedangkan ini hanya diberikan terhadap jalur pendidikan sekolah. Sedangkan jalur pendidikan luar sekolah tidak diperhatikan, sehingga kurang berperan sebagaimana diharapkan. Hal ini semakin diperparah lagi oleh adanya pengaruh global yang menerpa kehidupan keluarga yang selanjutnya berubah orientasi dan pola hidup. Yaitu pola hidup yang lebih mengutamakan material, tanpa diimbangi dengan dimensi spiritual. Akhirnya rumah tangga sebagai benteng pertahanan moral dan akhlak keluarga ikut terbawa hanyut arus global tersebut.

Dari segi tenaga pendidikan, tenaga pengajar merupakan tenaga pendidik yang khusus diangkat dengan tugas utama mengajar, yang pada jenjang pendidikan dasar menengah disebut guru dan pada jenjang tinggi disebut dosen. Secara kuantitatif dan kualitatif tenaga-tenaga kependidikan tersebut di atas, tampak belum memadai untuk keperluan berbagai lembaga pendidikan yang ada. hal ini dikarenakan keterbatasan pemerintahan untuk mengadakan tenaga-tenaga kependidikan tersebut.

Dari segi kurikulum, Sistem Pendidikan Nasional mengatakan, bahwa kurikulum disusun untuk mewujudkan tujuan pendidikan nasional dengan memperhatikan tahap 
perkembangan peserta didik dan kesesuainnya dengan lingkungan, kebutuhan pembangunan nasional, perkembangan ilmu pengetahuan dan teknologi serta kesenian, sesuai dengan jenis dan jenjang masing-masing satuan pendidikan. Kenyataan menunjukkan masih terdapat sejumlah pengetahuan yang diberikan di perguruan tinggi yang tidak adalagi relevansinya dengan kebutuhan masyarakat, sehingga lembaga pendidikan ikut andil dalam memperbanyak jumlah pengangguran intelektual. Selain itu masalah dikotomi antara ilmu agama dengan ilmu umum masih mewarnai kurikulum pendidikan pada umumnya. Untuk mengatasi masalah ini perluh segera dilakukan intergasi mata ilmu agama dengan ilmu umum.

\section{KESIMPULAN}

Dalam rangka membangun paradigma pendidikan nasional yang berorientasi kepada masyarakat, maka mau tidak mau harus meninjau kembali sistem pendidikan yang berlaku di Negara ini yang masih ada ditemukan titik-titik kelemahannya. Karena kalau hal ini terus dibiarkan, maka usaha untuk meningkatkan mutu dan martabat bangsa Indonesia agar mampu bersaing dan mencapai taraf yang sama dngan Negara-negara lain yang telah maju akan sulit tercapai, justru akan menyebabkan bangsa Indonesia tak akan sanggup berkompetisi dengan bangsa lain ditengah arus globalisasi yang makin penuh persaingan.

Dengan demikian, disarankan agar sektor pendidikan harus diberikan perhatian yang super ekstra, dengan pendidikan yang berkualitas diharapkan mampu menghasilkan manusia-manusia yang berkualitas pula dan mampu bersaing. Pendidikan Indonesia di masa mendatang harus mampu melahirkan manusia yang memiliki daya kompetisi yang tinggi, sehingga di mana pun ia berada, ia akan tetap sukses dan bertahan untuk kelangsungan hidupnya. 


\section{DAFTAR PUSTAKA}

Aly, Hery Nur, Ilmu Pendidikan Islam, Jakarta: Logos Wacana Ilmu, 1999. Al-Ali, Hasan Abd., Tarbiyah al-Islamiyah fi al-Qarniy al-Rabi' al-Hijry, Mesir: Dar al-Fikr, 1978

Arifin, M., Filsafat Pendidikan Islam, Cet.III; Jakarta: Bumi Aksara, 1993. Al-Attas, Syekh Muhammad al-Naquib, The Concept of Education in Islam, Kuala Lumpur: Muslim Youth Men of Malaysia ABM, 1980

Fadjar, A. Malik, Reorientasi Pendidikan Islam, Cet. I; Jakarta: Fajar Dunia, 1999.

Jalaluddin, Teologi Pendidikan, Jakarta: PT. RajaGrafindo Persada, 2001.

Kartono, Kartini, Pengantar Ilmu Pendidikan Teoritis, Bandung: Mandar

Maju, 1992.

Langgulung, Hasan, Beberapa Pemikiran tentang Pendidikan Islam,

Bandung: Al-Ma'arif, 1980

Husna, 1978

Mastuhu, Memberdayakan Sistem Pendidikan islam, Jakarta: Logos Wacana Ilmu, 1999.

Muhaimin, Paradigma Pendidikan Islam : Upaya Mengaktifkan Pendidikan Agama Islam di Sekolah, Bandung: PT. Remaja Rosdakarya, 2002.

Muhadjir, Noeng, Ilmu Pendidikan dan Perubahan SSosial : Suatu Teori Pendidikan, Yogyakarta, Rake Sarasin, 1987

Mujib, Abdul, Yusuf Mudzakkir, Ilmu Pendidikan Islam, Cet. I; Jakarta:

Kencana, 2006.

Nata, h. Abuddin, Ilmu Pendidikan Islam: dengan pendekatan multidisipliner

(Normatif Perenealis, sejarah, filsafat, Psikologi, Sosiologi, Manajemen, Teknologi, Informasi, Kebudayaan, Politik, Hukum, Ed. 1, Cet.II; Jakarta: Rajawali Press, 2010.

Rahardjo, Toto, Pendidikan Popular: Membangun Kesadaran Kritis, Cet. II;

Yogyakarta: Insist Press, 2005.

Al-Salam, Abd, Abd al-Wahab, Tarbiyah wa Fan al-Tadris, Mesir: Dar al-Salam, $1418 \mathrm{H}$.

Tafsir, Ahmad, Metodologi Pengajaran Agama Islam, Cet. III; Bandung:PT.

Remaja Rosdakarya, 1996. 
Tim Penyusun Kamus Pusat pembinaan dan Pengembangan Bahasa Departemen Pendidikan dab Kebudayaan, Kamus Besar Bahasa Indonesia, Jakarta: Balai Pustaka, 1994

Uhbiyati, Nur, Ilmu Pendidikan Islam, Edisi Revisi, Cet. II; Bandung: CV. Pustaka Setia, 1998 